\title{
Study on Brand Construction of Livestock Products of Leading Enterprises
}

\author{
Shidi Shao ${ }^{1, a}$, Yidan Shao ${ }^{2, b}$ and Xiwu Shao ${ }^{3, c^{*}}$ \\ ${ }^{1}$ Jilin Provincial Experimental Middle School, Changchun, China \\ ${ }^{2}$ China University of Mining and Technology, Beijing, China \\ ${ }^{3}$ College of Economics and Management, Jilin Agricultural University, Changchun, China \\ a547311649@qq.com, bsydlareina@163.com, 'xiwushao@126.com \\ *The corresponding author
}

Keywords: Leading enterprises; Livestock products; Brand

\begin{abstract}
Agricultural industrialization leading enterprises make use of capital, technology and talent advantages, driving the development of farmers, specialization, standardization, scale, intensive production. It is not only the important subject of modern agricultural system, but also the key to realize agricultural industrialization. As a form of industrial organization, the purpose of leading enterprises is to pursue profit maximization. Many leading enterprises involved in livestock production, processing and sales and other related business. This paper analyzes the agricultural industrialization leading enterprises in the importance of livestock product brand building and the main problems, from establishing animal products brand consciousness, pay attention to brand name and design, strengthening the brand marketing, etc, put forward the corresponding countermeasures, and finally put forward leading enterprises livestock product brand building several key problems needing attention.
\end{abstract}

\section{Introduction}

In 1950, the world's advertising master Ogilvy Levy published the article of "product and brand" in the "Harvard Business Review" , marking the beginning of modern brand theory research. In the 1990s, China's business community, academic community began to pay attention to the brand discussion and research. In 1998, some researchers began to explore the issue of agricultural products in China. Qinghua Chen Qinghua thought that the development of China's agricultural brand was far behind industrial products, agricultural products lacked domestic goods and well-known trademarks with high market share [1]; Jinsong Zhang thought that agricultural products with the brand are protected by law, to facilitate fair competition and stability of customers [2]; Yimen $\mathrm{Yu}$ thought that the implementation of agricultural brand strategy, the creation of agricultural products brand are strategic initiatives to adapt to agricultural industrialization needs under the conditions of the socialist market economy, to achieve that products can live in local, extend to whole country, and move towards to the international market[3].

Brand is an important source of strategic assets and core competitiveness, is the key to winning the enterprise market. World famous market strategist Jack Trot pointed out, in the analysis of the meaning of the future market brand, that there are two types of competitors are successful, one is a strong brand, a large brand, such companies can seek the interests around the world, the other is specialized or positioned good brand, which is some small competitors [4]. Brand building is an important strategy for China's agriculture to change the mode of economic growth from the resource economy, the real economy and the price economy to the symbolic economy, the relationship economy and the value of economic transformation. In the end of 2015, the amount of China's agricultural industrialization leading enterprises is 129,000 , playing an important role in increasing the income of farmers, promoting regional economic and social development. It is particularly important to strengthen the brand building of animal products of leading enterprises 
and improve their market competitiveness.

\section{Organization of the Text}

The Function of Brand Construction of Animal Products in Leading Enterprises of Agricultural Industrialization. Reduce choice cost for consumer. As a wide variety of livestock products, consumers are facing more and more optional information. If Consumers want to get some kind of product-related information, they need to take a certain amount of time cost and information costs. Brand as the spokesperson of the product endorsement, its basic characteristics and representative collection of information are relatively fixed, so the concept and product-related information can be better disseminated to the audience. Consumers use the brand for information collection, merit decisions, greatly reducing the cost of choice. For Leading enterprises, strengthening the livestock product brand building can reduce the cost of consumer choice, and enable consumers to form a stable brand loyalty.

Increase corporate profits, improve corporate reputation. Brand bearing the commitment of the product quality, easy to make consumers have the degree of trust and follow, and form brand reputation, thereby reducing product promotion costs. Brand animal products prices must be higher than the equilibrium price for enterprises to bring excess profits. Zhang Ruimin, Haier Group President, pointed out that if you have the brand, and you will have the market. Brand is the intangible assets of enterprises, such as: Shuanghui brand value of 49.7 billion yuan, 80.85 billion yuan for Erdos. For leading enterprises, strengthening the brand building of livestock product can improve product awareness, occupy more products market, increase corporate profits and promote the healthy development of enterprises.

Enhance the ability of farmers to get sustainable income. Leading enterprises establish a stable link mechanism with farmers through the implementation of order farming, each of them take what they need to achieve mutual win. "Huazheng" brand trademark of Jilin Huazheng Agriculture and Animal Husbandry Development Co., Ltd. acquired the Chinese well-known trademarks. Meat market share of Huazheng brand in Jilin Province ranks first, frozen goods are sold to 14 domestic provinces and cities, and exported to Hong Kong. Huazheng establish a benefit link mechanism with farmers, animal husbandry community in the method of contract, the two sides achieve to implement the contract management, driving more income for 20,000 farmers.

Promote regional economic and social development. Brand strategy, showing the continuous improvement of the enterprise in the level of enterprise technology, quality and integrity, is the combination of sustainable development and scientific development, plays a positive role in promoting the local economy and guiding the market behavior. Guizhou Yonghong Food Co., Ltd., the national leading enterprises, its products "Ngau Tau" are sold in 29 provinces, autonomous regions and municipalities, since 2003 , the company led the county more than 10,000 farmers keep beef cattle, driving farmers to increase income more than 5000 million, and local economic and social development.

The Existing Problems in the Brand Building of Livestock Products in Leading Enterprises of Agricultural Industrialization. Lack of brand awareness. The trend of modern agricultural development must be from the competition of primary product to the competition between the brands. At present, the core of leading enterprises production and operation is still in the simple product production and management, ignoring the brand building. Most of livestock products are simple to operate and do not fully exploit brand value. At present, the proportion of GDP created by the value of American brand products accounted for $60 \%$, while the proportion of China's GDP created by the Chinese brand products accounted for less than 20\% [5]. Most of our livestock products are concentrated on the primary areas, lack of intensive processing, having a weak market competitiveness.

Brand building in the initial stage. As the lack of brand awareness of livestock products, brand building is lack of macro guidance, the efforts on the formation, development, dissemination and protection of the brand to support the policy is not enough, resulting in brand building staying in the initial stage. July 2005, Haoyue beef, the only beef brand, are certificated as "China's top ten 
meat best-selling brand" by the Ministry of Commerce, is China's most market competitiveness brand and the first Muslim brand, but brand value of Haoyue is only 5 billion yuan. It shows that the scales for most of China's beef cattle slaughter and processing enterprises are relatively small, brand awareness is low, brand building has a long way to go.

Less well-known brands. Taking the 410 well-known trademark identified and published by 2012 State Administration for Industry and Commerce Trademark Office in the trademark management cases for example, livestock products, as well-known trademarks, is 18 pieces, accounting for only $4.4 \%$ of the total. Well-known brands are few, restricting the industrialization of agriculture leading enterprises in the rapid development.

Countermeasures for Brand Construction of Animal Products in Leading Enterprises of Agricultural Industrialization. Establish brand awareness. With the formation of the buyer's market for agricultural products, consumers' consuming behavior is shifting from past brand-free preferences to brand-name consumption. Therefore, the leading enterprises should establish brand awareness, the brands are the powerful weapons to extend a pioneering market and enhance the core competitiveness. Lynn Alsa of the United States believes that "when an enterprise is very clear about his business, his products and services provided in the market, the influence among consumers, and the influence of this knowledge, loyalty and association, and the ability to adopt appropriate strategies to integrate the brand into the lives of consumers and potential consumers, it means that he has cultivated his own brand awareness to some extent "[6]

Strengthen the awareness of brand application. Brand can lead the enterprise to win, when the international famous marketing master Milton Kotler were talking about China's manufacturing industry, he pointed out that "For high-quality products into the developed market, the quality and price control are not large, Chinese enterprises need to obtain $30 \%$ of the profits from brand, rather than $10-15 \%$ of the market processing fees. "[7] Therefore, the leading business managers should strengthen the brand awareness, reaching a consensus of the brand utility and value and the importance of using the brand, In the livestock production and business activities, they actively create and use the brand, so that the brand become the spokesperson of the product.

Strengthen the awareness of brand protection. Brand is a commercial term, only the timely registration, access to trademark exclusive rights, they can be protected by law. Chinese people's trademark awareness is weak, especially the trademark awareness of agricultural products. Therefore, the timely applying for registration for livestock products with good prospects. The Trademark Law of the People's Republic of China (2001) stipulates that natural persons, legal persons or other organizations shall apply for trademark registration to the Trademark Office if they need to obtain the exclusive right to produce, manufacture, process, pick or distribute the goods. The registered trademark is valid for 10 years. Where the registered trademark expires and needs to be used continuously, it shall apply for renewal of registration within 6 months before the expiry date. If the application fails to be made during this period, a grace period of 6 months may be granted. If the application has not been made at the expiration of the grace period, the registered trademark shall be canceled. Maintaining the brand's long-term vitality need to establish a good brand awareness, to prevent fake and shoddy products confusing consumers audiovisual.

Establish the awareness of brand development. Leading enterprises production and business operators approach the livestock products brand construction in the development of the eyes, and firmly establish the development of the brand, increase brand depth, continuously innovate brand ideas, to improve the brand's market image and brand competitiveness, so that the brand's intrinsic value can be full played. Only by continuously product technology innovation, improving the technological content of products, meeting consumer demand, maintaining high quality brand image, and through efficient brand promotion strategy, they can maintain the independence of the brand, and occupy a favorable market position.

Focus on brand naming and design. Brand naming and design are an important part of brand building, a good brand name can make the product get tens of billions of dollars in the whole life, because it passed some meaning itself, describing the strengths of the product, can be fast identified, and significantly differentiate the product from other competitors. [8] Livestock 
products brand name and design for leading enterprises of agricultural industrialization should highlight the following characteristics:

Ecology. Ecology refers to that the brand name should highlight the health, safety, pollution, green, environmental protection, natural and other characteristics, to meet the consumers' cultural psychology of back to peace, pastoral life demands, consistent with the city consumers desire natural and loving green .

Memorability. Easy to read is the most fundamental requirement for the brand name. Through the investigation and study, it shows that the average awareness ofr four-word brand name is $11.3 \%$, 7 word brand name is only $4.86 \%$, so the two syllables or 3 syllable brand name awareness are much higher.

Meaningfulness. It refers to fully reflect the benefits of product features to consumers. The essence of brand is culture, the brand should have cultural a certain meaning of connotations, can cause consumer associations.

Protectability. It refers to that the brand name can not have infringement activity, can not choose the same or similar registered brand name; at the same time, the brand name itself can be registered in line with the requirements of trademark law, subject to legal protection.

Strengthen brand marketing. Brand marketing refers to the marketing activities of enterprises to guide the brand image in the process of guiding goods or services from producers to consumers and users, through the creation of brand, to carry out brand strategy, focusing on shaping the brand image of the marketing activities and the process of branding .

Brand packaging of livestock products. Brand packaging is the brand personality into packaging visual effects, so that brand personality can be sensible and identifiable, it includes brand name, logo, standard Chinese and English characters, representative color, auxiliary color and so on. Many domestic animal products brand packaging is obsolete in China, can not reflect the product innovation and modern consciousness of brand-name enterprises. Good packaging is life-long advertising for the brand, according to a foreign statistics, it shows that 50-60\% of consumers are affected by the packaging and then produce the interest to purchase, forming purchase behavior.

Branding communication of livestock products. With the development of modern media, the time of "good wine is not afraid of the alley" is gone, good wine also need to propaganda. For livestock products brand communication, we must first highlight the ecological characteristics of the region. Such as Inner Mongolia animal product brand communication to highlight the grassland green ecological characteristics; Jilin Province to highlight the livestock products breeding, sources and production process of transmission. Second, combining with modern media, be informal. Such as the use of housing or garden walls, radio and television, newspapers and magazines, elevator or outdoor LED display, roadside billboards, bus advertising, the Internet, etc., we can also use public relations sponsorship or agricultural fair beef products exhibition and other forms of communication. But before the choice of media to accurately locate, that is, to determine the target consumer groups. According to the number, age, place of residence, eating preferences and others of potential consumers, to select the appropriate form of communication. Third, strengthen the site construction, to improve corporate reputation. Through the fifth batch of state-level agricultural industrialization leading enterprises website query, we found that many leading enterprises of the site construction are relatively backward, and some only have simple business description and contact information, the relevant content of animal products is less.

The Problems are Paid Attention to on Agricultural Livestock Products Brand Construction of Industrialization Leading Enterprises. Continue to focus on product quality. Sudanese red duck eggs, melamine milk powder and milk, formaldehyde milk sugar, clenbuterol, fake beef, double oxygen water chicken feet and other food safety incidents occur repeatedly, so that people pay more attention to food safety issues, which provides a serious and urgent proposition for livestock production, Processing, circulation and other aspects of agricultural industrialization leading enterprises. Therefore, in the long process of brand building, the leading enterprises must strictly manage quality control, win by quality, survive and develop by quality.

The communication of brand concept to be realistic. Product quality of brand communication 
and the company's services should be consistent with the reality. Such as the actual does not match, exaggerated, but the concept of speculation, make a big advertising, consumers have a feeling of being deceived after using the product, consumers began to transfer consumption, corporate profits will decline, and the brand will die.

The government should support it. For brand building, It is not enough to carry out the packaging and publicity, if the product want to reach a certain quality and a certain reputation, the relevant government departments need to assess. Government departments should strengthen management in accordance with the ISO international food standards system. Leading enterprises should also treat it as the goal, strictly control livestock products, make the product test, classification, grading packaging. All levels of government should regularly criticize brand-name products, especially make a dynamic supervision to ecological products, pollution-free, green, organic products, etc. Governments at all levels should strive to support the construction of livestock products, at the same time, they should use various media to increase awareness of brand-name livestock products.

Focus on strengthening the management of brand equity elements. The accumulation of brand equity is a combination of many factors for the consumer impression, elements of brand equity include a lot of contents, such as: enterprise scale, assets, technology level, product quality, market share, staff quality, corporate culture, service quality, brand packaging, brand communication and so on. Regardless that which brand image is damaged, it will affect the accumulation of brand equity and brand awareness. To create a supportive brand-name livestock products, we need to work from all aspects to strengthen the management of brand equity elements.

Combination should be done for the main and sub-brand. The main brand is the prerequisite and basis for the sub-brand, is the source of the survival of the sub-brand, out of the main brand, vice brand will lose their vitality. Sub-brand subordinate to the main brand, is the supplement, extension and progressive of the main brand. The two sides are interrelated, mutual advance, mutual blending. Enterprises invest a lot of resources to cultivate the main brand, rather than vice brand. Accordingly, the advertising audience, consumer identification, memory and brand recognition, close and loyalty of the main body are the main brand. Different livestock products attached brand personality of the sub-brand to highlight the product characteristics. In order to achieve a good combination of the main and sub-brands, it must make a reasonable positioning for the sub-brand. Sub-brand positioning should lock the target consumers, to create product differentiation advantages, to strengthen the product image and highlight the product personality.

\section{References}

[1] C.H Chen, R.Z Lv, Thoughts on the brand issue of agricultural products [J]. China Food Economy, 1998 (6).

[2] J.S Zhang, D.W He, Discussion on the brand of agricultural products [J]. Rural Economy, 1998 (11).

[3] Y.M Yu, Z.H Li and Y.C Fang, The creation and maintenance of famous agricultural products

[4] Ai Reese, Jack Trot. Marketing war [M]. Beijing: China Finance and Economics Press, 2002 (1).

[5] Many domestic companies lack awareness of the brand, teach you how to do the brand. Http: //info.123cha.com,2012-03-08.

[6] M.L Chen, China's corporate brand marketing and strategic design [J]. Chinese Business Community, 2008 (7).

[7] Brand building is the only way for the development of industrial products,

[8] Brand elements, http://www.docin.com. 